\title{
Comparação das Alterações Histológicas da Medula Espinal e Neurológicas de Cobaias após Anestesia Subaracnóidea com Grandes Volumes de Bupivacaína Racêmica, de Mistura com Excesso Enantiomérico de $50 \%$ de Bupivacaína (S75-R25) e de Levobupivacaína*
}

Comparison of Histologic Spinal Cord and Neurologic Changes in Guinea Pigs after Subarachnoid Block with Large Volumes of Racemic Bupivacaine, 50\% Enantiomeric Excess Bupivacaine (S75-R25), and Levobupivacaine

\author{
Paulo de Oliveira Vasconcelos Filho, TSA ${ }^{1}$, Irimar de Paula Posso, TSA², Mariza Capelozzi', Vera Luiza Capelozzi ${ }^{3}$
}

\section{RESUMO}

Vasconcelos Filho PO, Posso IP, Capelozzi M, Capelozzi VL - Comparação das Alterações Histológicas da Medula Espinal e Neurológicas de Cobaias após Anestesia Subaracnóidea com Grandes Volumes de Bupivacaína Racêmica, de Mistura com Excesso Enantiomérico de $50 \%$ de Bupivacaína (S75-R25) e de Levobupivacaína.

JUSTIFICATIVA E OBJETIVOS: A levobupivacaína apresenta menos efeitos colaterais sobre o sistema nervoso central do que os induzidos pela bupivacaína racêmica; entretanto, o efeito anestésico é menos intenso. Foi realizado estudo experimental para comparar efeitos adversos de grandes volumes de bupivacaína, de bupivacaína S75-R25 e de levobupivacaína quando injetados no espaço subaracnóideo de cobaias.

MÉTODO: Quarenta cobaias foram divididas em quatro grupos. Anestesiadas com $\mathrm{O}_{2}$ a $100 \%$ e isoflurano a $2 \%$, com posterior punção no espaço intervertebral $L_{6}-S_{1}$. Nos animais do Grupo I foram administrados $2 \mathrm{~mL}$ de solução fisiológica a 0,9\%; no Grupo II, $2 \mathrm{~mL}$ de bupivacaína 0,5\%; no Grupo III, $2 \mathrm{~mL}$ de bupivacaína S75-R25 0,5\% e no Grupo IV, $2 \mathrm{~mL}$ de levobupivacaína 0,5\%. Após o despertar, nos momentos 0, 60, 120 e 180 minutos, foi realizado exame neurológico, diariamente, por uma semana. Os animais foram sacrificados e submetidos à perfusão com paraformaldeído a 4\%. Após a fixação, a medula espinal foi isolada por dissecção e analisada histologicamente para avaliação do grau de lesão medular.

RESULTADOS: As cobaias do grupo-controle não apresentaram bloqueio nervoso. As do Grupo II apresentaram bloqueio sensitivo e motor por mais de 180 minutos. Nos Grupos III (S75-R25) e IV (levobupivacaína) houve bloqueios motor e sensitivo no momento 0 minuto; contudo, no momento 60 minutos o bloqueio motor era mínimo. Ao exame histológico, o Grupo I não apresentou alterações. No Grupo II foram encontradas alterações medulares intensas. Nos Grupos III e IV as alterações medulares foram pouco intensas.

${ }^{*}$ Recebido da (Received from) Disciplina de Anestesiologia da Faculdade de Medicina da Universidade de São Paulo (FM/USP), São Paulo, SP

1. Doutor pela FM/USP

2. Professor Doutor da Disciplina de Anestesiologia da FM/USP

3. Professora Doutora da Disciplina de Imunopatologia da FM/USP

Apresentado (Submitted) em 18 de maio de 2007

Aceito (Accepted) para publicação em 19 de fevereiro de 2008

Endereço para correspondência (Correspondence to):

Dr. Paulo de Oliveira Vasconcelos Filho

Rua Napoleão de Barros, 420/21 - Vila Clementino

04024-001 São Paulo, SP

E-mail: paulovasco@usp.br

(C) Sociedade Brasileira de Anestesiologia, 2008
CONCLUSÕES: A levobupivacaína em grandes volumes causou pouco dano ao sistema nervoso, comparada com a bupivacaína. Entre levobupivacaína e bupivacaína S75-R25, não houve diferença estatística significativa.

Unitermos: ANESTÉSICOS, Local: bupivacaína, bupivacaína S75-R25, levobupivacaína; ANIMAL: cobaia; COMPLICAÇÕES: lesão neurológica, neurotoxicidade; TÉCNICAS ANESTÉSICAS: Regional: subaracnóidea.

\section{SUMMARY}

Vasconcelos Filho PO, Posso IP, Capelozzi M, Capelozzi VL - Comparison of Histologic Spinal Cord and Neurologic Changes in Guinea Pigs after Subarachnoid Block with Large Volumes of Racemic Bupivacaine, 50\% Enantiomeric Excess Bupivacaine (S75-R25), and Levobupivacaine.

BACKGROUND AND OBJECTIVES: Levobupivacaine has less central nervous system side effects than racemic bupivacaine, but its anesthetic effect is not as intense. The objective of this experimental study was to compare the adverse effects of large volumes of bupivacaine, S75-R25 bupivacaine, and levobupivacaine injected in the subarachnoid space of guinea pigs.

METHODS: Forty guinea pigs were divided in four groups. They were anesthetized with $100 \% \mathrm{O}_{2}$ and $2 \%$ isoflurane, followed by puncture of the $L_{-}-S_{1}$ intervertebral space. In Group I, $2 \mathrm{~mL}$ of normal saline were injected; in Group II, $2 \mathrm{~mL}$ of $0.5 \%$ bupivacaine; in Group III, $2 \mathrm{~mL}$ of 0.5\% S75-R25 bupivacaine, and in Group IV, $2 \mathrm{~mL}$ of 0.5\% levobupivacaine. After the animal awakened, neurological exam was done at $0,60,120$, and 180 minutes, and daily for one week. Animals were killed and underwent perfusion with $4 \%$ paraformaldehyde. After fixation, the spinal cord was isolated by dissection and analyzed histologically to evaluate the degree of spinal cord lesions.

RESULTS: Guinea pigs in the control group did not present nervous block. Those in Group II presented sensitive and motor block for more than 180 minutes. Animals in Groups III (S75-R25) and IV (levobupivacaine) developed sensitive and motor blockade at moment 0 , but at 60 minutes the motor blockade was minimal. Histologic exam in Group I showed no changes. In Group II, severe spinal cord changes were observed. In Groups III and IV, spinal cord changes were mild.

CONCLUSIONS: Large volumes of levobupivacaine caused little damage in the central nervous system when compared with bupivacaine. Statistically significant changes were not observed between levobupivacaine and S75-R25 bupivacaine.

Key Words: ANESTHETICS, Local: bupivacaine, S75-R25 bupivacaine, levobupivacaine; ANESTHETIC TECHNIQUE, Regional: subarachnoid; ANIMAL: guinea pigs; COMPLICATIONS: neurologic lesion, neurotoxicity. 


\section{INTRODUÇÃO}

O cloridrato de bupivacaína é um anestésico local existente há mais 30 anos, muito utilizado em anestesias regionais. A forma disponível para uso clínico é a bupivacaína racêmica, uma mistura de formas isoméricas (SR50). A duração de ação é longa (4 a 12 horas), com início de ação lento (10 a 30 minutos) e o pH da solução está entre 4,6 e 6,0 . Ambas as formas de bupivacaína, tanto a forma $R(+)$ quanto a $\mathrm{S}(-)$, possuem ações anestésicas, mas com diferente poder de penetração nas camadas lipofílicas, e receptores específicos de canais de sódio. Assim, há uma diferenciação nos efeitos da forma $R(+)$, mais tóxica, em relação à forma $\mathrm{S}(-)$. $\mathrm{Na}$ farmacodinâmica da bupivacaína racêmica, destaca-se a sua cardiotoxicidade, quando da injeção vascular acidental ${ }^{1-5}$. A levobupivacaína é o S-enantiômero da bupivacaína. Protocolos pré-clínicos sugerem que a levobupivacaína tem uma potência similar à da bupivacaína enquanto exibe, significativamente, menor cardiotoxicidade e neurotoxicidade ${ }^{6-10}$.

A mistura com excesso enantiomérico de $50 \%$ de bupivacaína (S75-R25) é o resultado da pesquisa por um anestésico local que apresentasse características de bloqueio neural de longa duração, mas com menor toxicidade sistêmica. Em modelo experimental em nervo isquiático de rato, foi comprovado que a S75-R25 mantém as propriedades anestésicas locais da SR50. Posteriormente, também foi demonstrado em ratos que a S75-R25 em bolus, por via venosa, possui menor cardiotoxicidade que a SR50, atribuindo-se este efeito à diminuição do isômero $R(+)$ na composição do novo fármaco ${ }^{11-13}$. $\mathrm{Na}$ década de 1990, foram descritos casos de paresias, parestesias e síndrome de cauda eqüina, que foram associados a maior quantidade de anestésicos locais administrados no espaço subaracnóideo ${ }^{14,15}$. Os anestésicos eram administrados através de microcateter inserido por agulha com ponta de lápis de pequeno calibre ${ }^{16,17}$. Os pacientes que apresentaram seqüelas receberam injeções repetidas, em decorrência de bloqueios inadequados, ou injeção de grandes volumes, que deveriam inicialmente ser administrados no espaço peridural e acidentalmente foram introduzidos no espaço subaracnóideo. A síndrome da cauda eqüina consiste nas disfunções urinária e intestinal, perda de sensibilidade na região do períneo e graus variáveis de fraqueza muscular nos membros inferiores 14,17,18.

O objetivo desse estudo experimental foi comparar os efeitos de grandes volumes de bupivacaína e levobupivacaína injetados no espaço subaracnóideo de cobaias. Comparação com base em alterações da medula espinal, associada ao exame neurológico, permitiu a confirmação do bloqueio anestésico após a realização da punção.

\section{MÉTODO}

Após a aprovação da Comissão de Análise de Projetos de Pesquisa (CAPPesq) do Hospital das Clínicas da FMUSP, foram utilizadas 40 cobaias fêmeas, pesando entre 400 e $600 \mathrm{~g}$ para o estudo. Foram divididas de modo aleatório em quatro grupos, conforme a solução. $O$ modelo de punção única em cobaias foi estabelecido na instituição após publicação em $1998{ }^{19}$.

Com um jejum prévio de duas horas, a cobaia era posicionada em decúbito ventral e anestesiada com $\mathrm{O}_{2}$ a $100 \%$ e isoflurano a $2 \%$. Foi instalado oxímetro de pulso para medida da saturação periférica de oxigênio, cujo sensor foi colocado na pata anterior direita. Foi realizada a palpação das duas tuberosidades do osso ilíaco e do processo espinhoso da última vértebra lombar. Logo abaixo, localizava-se o espaço lombossacral. Foram realizadas tricotomia, anti-sepsia e anestesia local com lidocaína a $2 \%$. Logo após, o animal era posicionado para punção subaracnóidea com escalpe 23-gauge no espaço intervertebral $\mathrm{L}_{6}-\mathrm{S}_{1}$. Aleatoriamente, os animais recebiam as soluções e eram divididos nos seguintes grupos: nos animais do Grupo I, foram administrados $2 \mathrm{~mL}$ de solução fisiológica a $0,9 \%$ (grupo-controle); nos animais do Grupo II, $2 \mathrm{~mL}$ de bupivacaína 0,5\%; no Grupo III, $2 \mathrm{~mL}$ de bupivacaína (S75-R25) 0,5\%, e no Grupo IV, $2 \mathrm{~mL}$ de levobupivacaína $0,5 \%$.

$\mathrm{O}$ exame neurológico utilizado teve como base o realizado por Ready e col. em ratos, em $1985{ }^{20}$. Após o despertar do animal, nos momentos $0,60,120$ e 180 minutos, foi feito um exame neurológico, que foi repetido nos dias posteriores até completar uma semana, quando então o animal foi sacrificado. O exame foi restrito a três funções neurológicas: habilidade de andar, flexão da pata posterior e sensação cutânea, e estes foram pontuados conforme o seguinte critério: 0 normal; 1 - diminuído e 2 - ausente. A habilidade de andar foi avaliada com a colocação do animal no chão e a observação das suas tentativas de andar. A flexão da pata posterior é uma característica do animal logo que é levantado de uma superfície. A sensação cutânea foi avaliada por meio da pesquisa de resposta aversiva a uma estimulação de um estimulador de 100 milivolts em dois pontos da pele. A verificação da quantidade de lesões clínicas proporcionada pelas soluções foi determinada com a soma dos pontos dos três exames. Cada animal teve supridas suas necessidades de alimento e água durante o estudo.

Após os sete dias de exame neurológico, os animais foram sacrificados com pentobarbital sódico $\left(200 \mathrm{mg} \cdot \mathrm{kg}^{-1}\right.$, por via intraperitoneal). Depois, foram submetidos à perfusão com $200 \mathrm{~mL}$ de paraformaldeído a 4\%, para exsanguinação, por meio de lesão em átrio ou câmara cardíaca direita e punção de ventrículo esquerdo, por onde foram injetados os $200 \mathrm{~mL}$ de paraformaldeído com bomba de infusão. Imediatamente, a coluna vertebral dos animais era dissecada da região cervical até a região sacral, e, depois, retirada e fixada em formalina neutra tamponada a $10 \%$ por 48 horas e posterior descalcificação por 48 horas. Posteriormente, foi realizado estudo macroscópico da coluna vertebral e medula espinal 
da cobaia. Finalmente, cortes de $5 \mathrm{~mm}$ de espessura foram efetuados ao longo de toda a coluna vertebral e processados para exame histológico.

Os cortes histopatológicos foram examinados à microscopia óptica em vários aumentos. Os componentes histológicos dos vasos e das estruturas neurais medulares em vários níveis foram medidos morfometricamente e comparados entre os quatro grupos.

Para comparar as alterações morfológicas detectadas em cada grupo, foi realizada a Análise de Variância (ANOVA) como método estatístico, sendo considerados significativos os valores de $p<0,05$.

\section{RESULTADOS}

Não houve perda de sensibilidade cutânea nem comprometimento de função motora, em qualquer momento no grupocontrole, no qual foi administrada solução fisiológica a 0,9\%, indicando que não houve trauma mecânico pela agulha, ou pelo volume, durante a injeção. Todos os animais que receberam solução de anestésico local tiveram bloqueio nervoso, caracterizado pelas ausências de: sensibilidade cutânea em áreas lombares e sacrais; flexão de patas posteriores e locomoção (habilidade de andar), quando acordaram da anestesia geral. O Grupo II (bupivacaína racêmica) apresentou bloqueio sensitivo e motor por mais de 180 minutos e bloqueio residual, caracterizado por falta de sensibilidade a estimulação elétrica, que persistiu por 24 horas. Nos Grupos III e IV, houve bloqueio sensitivo e motor logo após a punção, mas aos 60 minutos, o bloqueio motor estava parcialmente presente e o bloqueio sensitivo permaneceu por três horas (Figura 1).

A análise de alterações histológicas nas partes cervicais e sacrais da medula espinal não demonstrou diferenças significativas entre os grupos. As figuras 2 e 3 ilustram as diferenças do volume celular neuronal entre os grupos. Tanto na região torácica $(p=0,002)$ quanto na região lombar $(p=$ $0,008)$ da medula espinal das cobaias, houve diminuição significativa do volume celular neuronal no Grupo II (bupivacaína) em relação aos outros grupos.

Nas figuras 4 e 5 é possível comparar o tamanho do volume do edema entre os grupos. Também houve aumento no volume do edema, na medula torácica $(p=0,015)$ e na medula lombar $(p=0,003)$. Apesar das alterações morfológicas no Grupo III (S75-R25) serem maiores que no Grupo IV (levobupivacaína), não houve diferença estatística significativa em relação ao grupo-controle. A figura 6 apresenta a imagem histológica nos diferentes grupos.

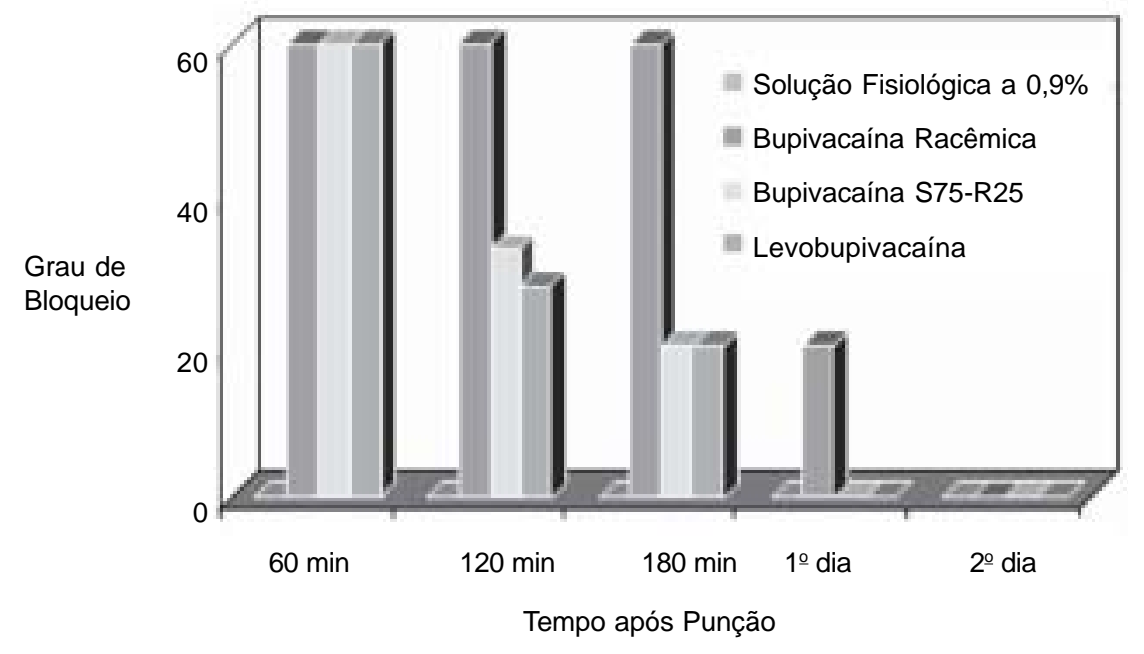

Figura 1 - Extensão do Bloqueio Neurológico após a Injeção Subaracnóidea dos Anestésicos. O resultado obtido com a soma dos três componentes do exame neurológico realizado (habilidade de andar, flexão de perna e sensibilidade cutânea). 


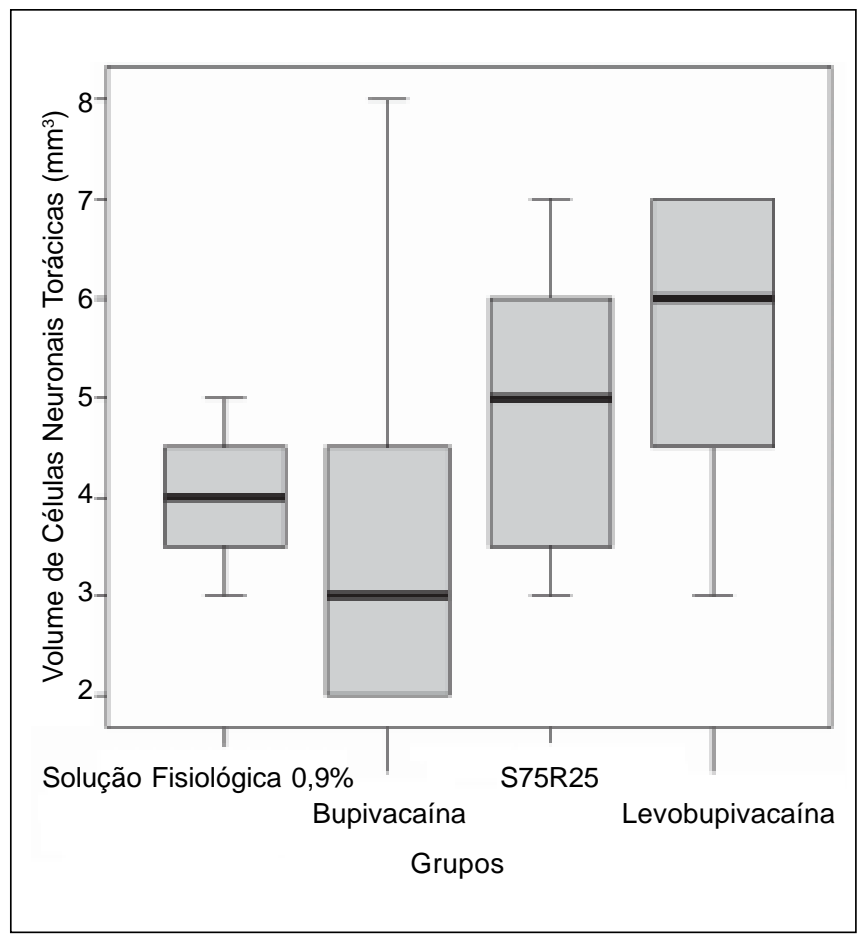

Figura 2 - Diferenças entre os Volumes de Células Neuronais, na Medula Espinal Torácica de Cobaias, após Punção Subaracnóidea com Altos Volumes de Bupivacaína, Bupivacaína S75-R25 e Levobupivacaína.

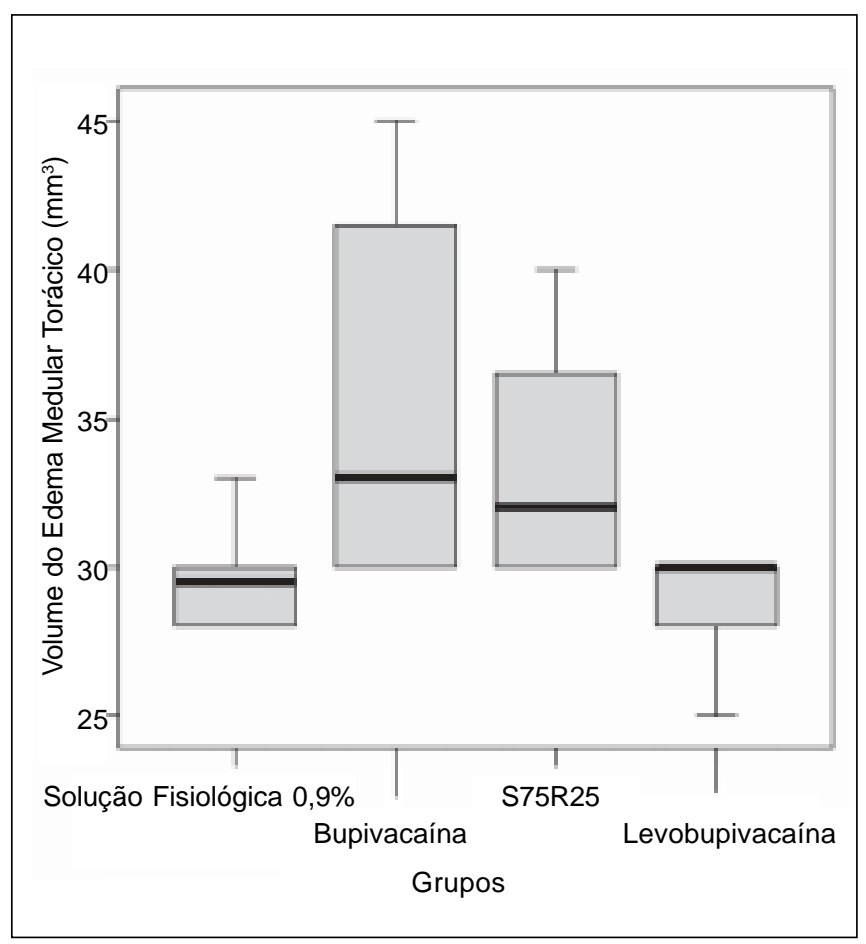

Figura 4 - Diferenças entre os Volumes de Edema da Medula Espinal Torácica de Cobaias após Punção Subaracnóidea com Altos Volumes de Bupivacaína, Bupivacaína S75-R25 e Levobupivacaína.

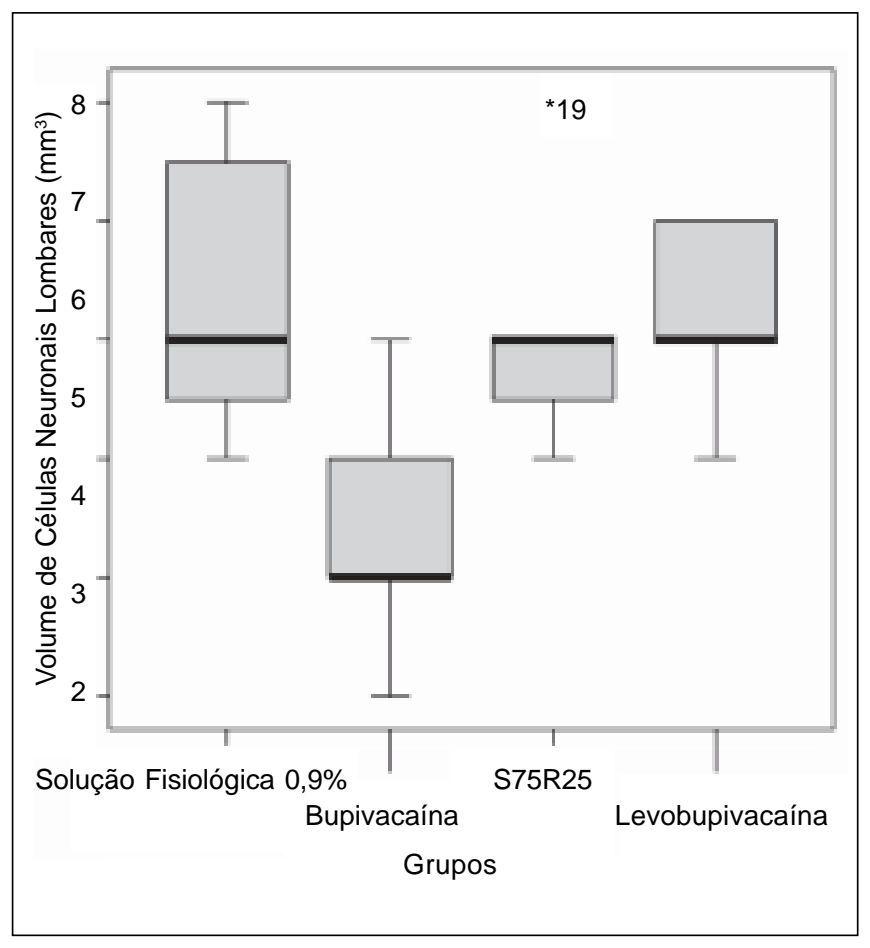

Figura 3 - Diferenças entre os Volumes de Células Neuronais na Medula Espinal Lombar de Cobaias após Punção Subaracnóidea com Altos Volumes de Bupivacaína, Bupivacaína S75-R25 e Levobu-pivacaína.

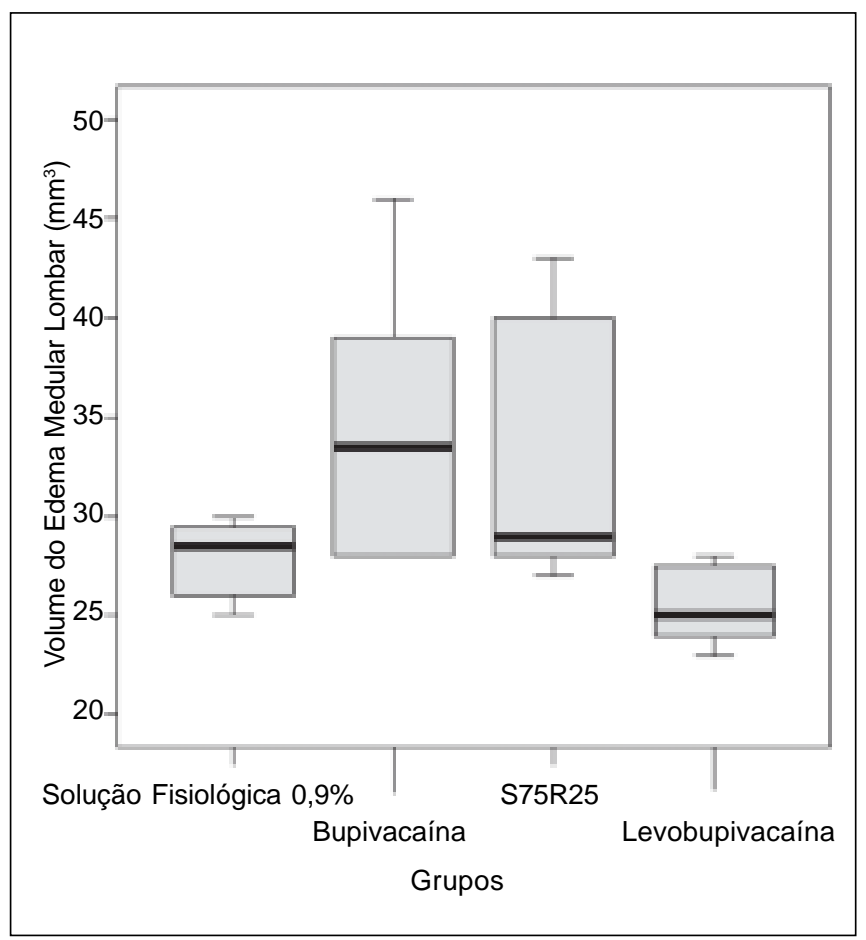

Figura 5 - Diferenças entre os Volumes de Edema da Medula Espinal Lombar de Cobaias, após Punção Subaracnóidea com Altos Volumes de Bupivacaína, Bupivacaína S75-R25 e Levobupivacaína. 


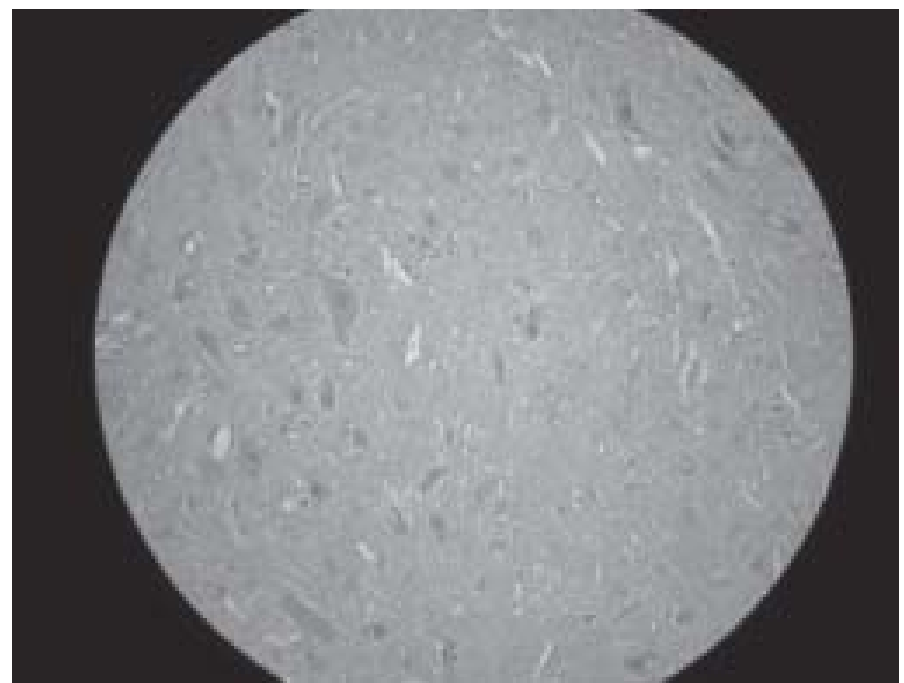

Grupo Controle

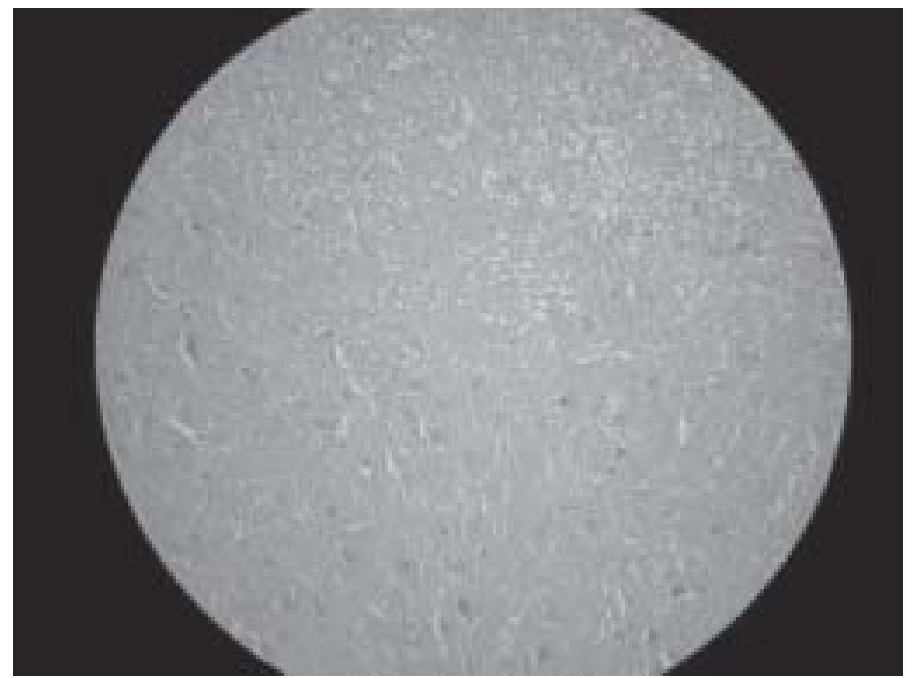

Bupivacaína S75-R25

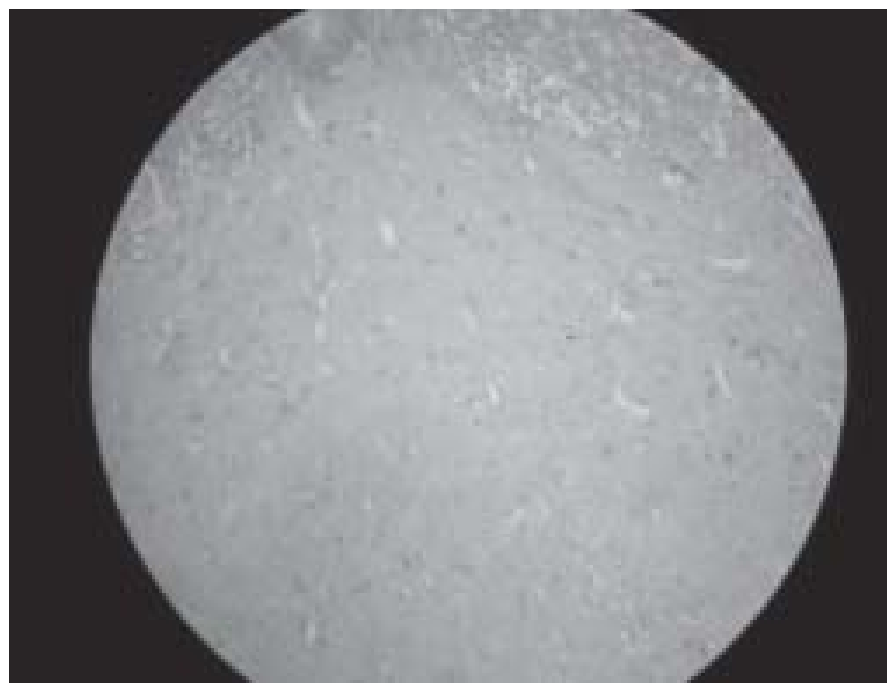

Bupivacaína

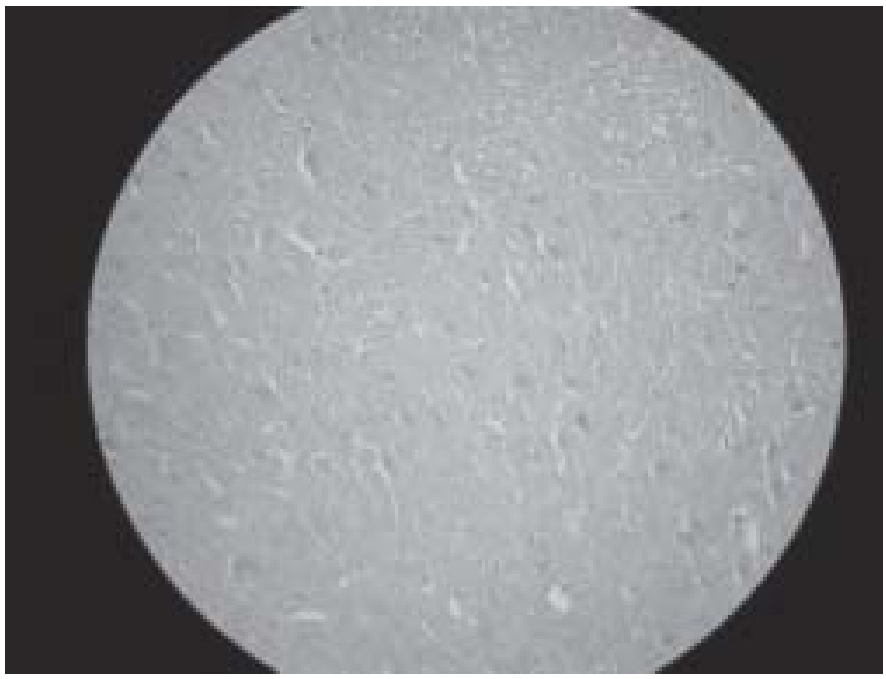

Levobupivacaína

Figura 6 - Visão Microscópica da Medula Espinal de Cobaias (Nível Lombar) após a Administração das Respectivas Substâncias.

\section{DISCUSSÃO}

Nesse estudo, foram encontradas poucas alterações histológicas na medula espinal de cobaias, em contato com grandes volumes de levobupivacaína e a bupivacaína S75R25, sem diferença estatística significativa em relação ao grupo-controle. $\mathrm{Na}$ administração de grandes volumes de bupivacaína houve dano ao sistema nervoso, com diferença estatística significativa, na comparação entre os grupos. Os resultados do estudo demonstraram que a levobupivacaína e a bupivacaína S75-R25, em grandes volumes, produzem bloqueios sensitivo e motor reversíveis, mesmo quando acidentalmente administradas. O comportamento da levobupivacaína foi bem similar a administração de solução fisiológica a $0,9 \%$. A utilização de grandes volumes de bupivacaína SR50 determinou o surgimento de altera- ções medulares intensas, quando comparada com os outros grupos.

Kanai e col., em estudo comparativo entre a bupivacaína, a ropivacaína e a levobupivacaína em administração peridural e subaracnóidea em ratos, mostraram que a levobupivacaína apresentava um efeito antinociceptivo maior do que o efeito da ropivacaína e comparável com o da bupivacaína nas concentrações de 0,25 a $0,75 \%$. Quando a ropivacaína e a levobupivacaína foram administradas no espaço subaracnóideo, em concentrações eqüipotentes, causaram bloqueio motor de duração similar. Quando foram comparados com a bupivacaína racêmica, em baixas concentrações, os dois anestésicos apresentaram uma menor duração do bloqueio. Entretanto, em altas concentrações, a duração do bloqueio dos três anestésicos locais foi semelhante. 
COMPARISON OF HISTOLOGIC SPINAL CORD AND NEUROLOGIC CHANGES IN GUINEA PIGS AFTER SUBARACHNOID BLOCK WITH LARGE VOLUMES OF RACEMIC BUPIVACAINE, 50\% ENANTIOMERIC EXCESS BUPIVACAINE (S75-R25), AND LEVOBUPIVACAINE

Uma questão de interesse é saber até que ponto os modelos experimentais podem ser úteis na identificação de neurotoxicidade dos anestésicos locais. Há alguns modelos experimentais de estudo de anestesia regional em pequenos animais ${ }^{20-23}$. Em 1998, um modelo de anestesia regional em cobaias foi descrito, com uma punção única paramediana com agulha 23-gauge no espaço intervertebral $\mathrm{L}_{6}-\mathrm{S}_{1}$. Os autores demonstraram que com a administração de azul-de-metileno, a punção alcançava o espaço subaracnóideo, sem lesão à medula espinal nem lesão de raízes nervosas que pudessem ser produzidas pela colocação da agulha ${ }^{19}$. Parte desse modelo foi utilizada, sem a administração do azul-de-metileno, mas com a comprovação da anestesia efetiva pela realização do exame clínico-neurológico. A cobaia foi o animal escolhido, pois é dócil e de fácil avaliação, sendo conveniente para o estudo. Para menor sofrimento do animal, optou-se pela utilização de anestesia geral inalatória, o que também permitiu imobilização total do animal, para o procedimento. Como a medula espinal da cobaia progride até a área lombar, foi escolhido o espaço intervertebral após a coluna lombar $\left(\mathrm{L}_{6}-\mathrm{S}_{1}\right)^{18,24}$.

Pouco se conhece sobre os mecanismos pelos quais os anestésicos locais produzem lesões nos nervos. Sabe-se apenas que as alterações clínicas, ao se manifestarem, produzem lesões suficientemente graves para ocasionar a perda da condução de algumas populações de fibras nervosas ${ }^{15-17}$. Sabe-se que, após a administração subaracnóidea de anestésico local, o metabolismo da medula espinal pode diminuir em decorrência do intenso bloqueio sensitivo e motor que é estabelecido. É possível que o anestésico local, em elevadas concentrações, determine bloqueio irreversível no transporte intracelular, e esse fato possa contribuir para o desenvolvimento de paresias e paralisias que se observam após a realização de bloqueios regionais. A morte celular não é necessariamente obrigatória para que existam alterações funcionais, porque reações tóxicas em qualquer população de células ou de receptores podem influenciar na função neurológica ${ }^{16,20,25}$.

Quando grandes volumes de anestésico local são inadvertidamente injetados no espaço subaracnóideo, os efeitos de tamponamento e diluição do mesmo, que normalmente ocorrem com pequenos volumes, deixam de existir. Aumenta a possibilidade de maior exposição da porção lombar e sacral da medula e das raízes nervosas sacrais ao anestésico local. Em geral, os vasos sangüíneos medulares se dilatam, podendo sofrer processo de vasoconstrição, com a possível ocorrência de sofrimento medular ${ }^{20,25}$.

O volume de anestésico utilizado, nesse estudo, foi cerca de quatro vezes maior que a dose preconizada para anestesia do animal. Estudos piloto anteriores demonstraram que volumes menores não permitiam identificar um número de lesões neurológicas que diferissem muito do grupocontrole. Para que ocorram alterações celulares, como apoptose e morte celular, as concentrações de anestésico local devem ser superiores àquelas que bloqueiam os canais de sódio de maneira reversível. A utilização de altas concentrações pode produzir alterações neurológicas permanentes ${ }^{19,26}$.

Estudos sobre toxicidade de anestésicos locais possuem métodos de intensa manipulação dos animais estudados, com colocação de cateteres e possibilidade de traumatismo medular. Os novos estudos buscam encontrar dose mínima efetiva de anestésico local (MLAC), e são poucos sobre grandes volumes. A busca por método menos traumático permite maior confiança nos resultados.

Injeção acidental de grandes volumes de anestésico local no espaço subaracnóideo é uma possível complicação da anestesia peridural ${ }^{14,15}$. Nos últimos anos, com a possibilidade da administração peridural de anestésicos locais com menores efeitos colaterais, há maior segurança no emprego da técnica anestésica ${ }^{9,13}$.

A levobupivacaína em grandes volumes causou pouco dano ao sistema nervoso, comparada com a bupivacaína. Entre levobupivacaína e bupivacaína S75-R25, não houve diferença estatística significativa.

\section{Comparison of Histologic Spinal Cord and Neurologic Changes in Guinea Pigs after Subarachnoid Block with Large Volumes of Racemic Bupivacaine, 50\% Enantiomeric Excess Bupivacaine (S75- R25), and Levobupivacaine}

Paulo de Oliveira Vasconcelos Filho, TSA, M.D.; Irimar de Paula Posso, TSA, M.D.; Mariza Capelozzi, M.D.; Vera Luiza Capelozzi, M.D.

\section{INTRODUCTION}

Bupivacaine hydrochloride is a local anesthetic, which has been available for more than 30 years, commonly used in regional blocks. Racemic bupivacaine, a mixture of isomeric forms (SR50), is the presentation available for clinical use. It has a long duration of action (4 to 12 hours), slow onset of action (10 to 30 minutes), and it has a pH between 4.6 and 6.0. Both forms of bupivacaine, $\mathrm{R}(+)$ and $\mathrm{S}(-)$, have anesthetic activity, but with different penetration on lipophilic layers and specific sodium channel receptors. Thus, there is a difference between the effects of the $\mathrm{R}(+)$ isomer, more toxic, and the $S(-)$ isomer. The pharmacodynamics of racemic bupivacaine is marked by its cardiotoxicity when injected accidentally in the intravenous space ${ }^{1-5}$.

Levobupivacaine is the S-enatiomer of bupivacaine. Preclinical protocols suggest that the potency of levobupivacaine is similar to bupivacaine, while exhibiting less cardio- and neurotoxicity ${ }^{6-10}$. 
The $50 \%$ enantiomeric excess mixture bupivacaine (S75R25) resulted from the search for a local anesthetic with characteristics of long lasting neural blockade but with less systemic toxicity. It was demonstrated, in the experimental model of rat sciatic nerve, that S75-R25 maintains the local anesthetic properties of SR50. Afterwards, it was also shown in rats that the intravenous administration of a bolus dose of S75-R25 is less cardiotoxic than SR50, and this characteristic was attributed to the reduction of the $R(+)$ isomer in the new drug ${ }^{11,13}$.

In the decade of 1990, cases of paresis, paresthesias, and cauda equina syndrome, which were associated with the administration of a larger volume of local anesthetics in the subarachnoid space ${ }^{14,15}$, were reported. Anesthetics were administered through microcatheters inserted through a small caliber, pencil-point needle ${ }^{16,17}$. Patients who presented sequelae had received repeated injections due to inadequate block or injection of large volumes that should have been administered in the epidural space but were accidentally injected in the subarachnoid space. The cauda equina syndrome consists of urinary and bowel dysfunction, loss of sensitivity in the perineal area, and variable degrees of muscle weakness in the lower limbs ${ }^{14,17,18}$.

The objective of this experimental study was to compare the effects of large volumes of bupivacaine and levobupivacaine administered in the subarachnoid space of guinea pigs. Spinal cord changes associated with changes in neurological exams, which allowed the confirmation of anesthetic block after the puncture, were compared.

\section{METHODS}

After approval by the Research Project Analysis Commission (CAPPesq) of the Hospital das Clínicas of FMUSP, 40 female guinea pigs, weighing between 400 and $600 \mathrm{~g}$, were used in this study. The animals were randomly divided in four groups, according to the solution that was administered. The model of a single puncture in guinea pigs was established in the institution after being published in $1998{ }^{19}$.

After fasting for 2 hours, the guinea pig was placed in ventral decubitus and anesthetized with $100 \% \mathrm{O}_{2}$ and $2 \%$ isoflurane. A pulse oximeter was placed on the right anterior paw to determine the peripheral oxygen saturation. The two iliac tuberosities and the spinous process of the last lumbar vertebra were palpated. The lumbosacral space was immediately below the spinous process of the last lumbar vertebra. The area was shaved and cleaned, and anesthetized with $2 \%$ lidocaine. The animal was, then, positioned for subarachnoid puncture with a 23-gauge scalpel in the $L_{6}-S_{1}$ space. Animals received the different solutions randomly, being divided in four groups: in Group I, $2 \mathrm{~mL}$ of normal saline was administered (control group); in Group II, $2 \mathrm{~mL}$ of $0.5 \%$ bupivacaine; in Group III, $2 \mathrm{~mL}$ of $0.5 \%$ bupivacaine (S75-R25); and in Group IV, $2 \mathrm{~mL}$ of $0.5 \%$ levobupivacaine.
The neurological exam was based on the neurological exam conducted by Ready et al. in rats in $1985^{20}$. It was performed after awakening on moments $0,60,120$, and 180 minutes, and repeated on the following days, for a total of seven days; the animal was, then, killed. The exam was restricted to three neurological functions: ability to walk, flexion of the hind paw, and cutaneous sensitivity, which received the following scores: 0 - normal; 1 - reduced; and 2 - absent. Ability to walk was evaluated by placing the animal on the ground and observing its attempts to walk. Flexion of the posterior paw is done, characteristically, when the animal is lifted from a surface. Cutaneous sensitivity was evaluated by the aversive response to the stimulus of a 100-millivolts stimulator in two skin areas. Evaluation of the amount of clinical lesions caused by the different solutions was determined by the sum of the scores of the three areas. Water and food were provided for the animals during the study.

After seven days of neurological exams, animals were killed with sodium pentobarbital (200 mg. $\mathrm{kg}^{-1}$ intraperitoneal). Afterwards, they underwent perfusion with $200 \mathrm{~mL}$ of $4 \%$ paraformaldehyde for exsanguination through a lesion in the atrium or right cardiac chamber and puncture of the left ventricle for the administration of the paraformaldehyde with an infusion pump. The spinal cord was dissected immediately, from the cervical to the sacral region, removed and fixed in buffered neutral formalin at $10 \%$ for 48 hours, followed by decalcification for another 48 hours. Macroscopic exam of the vertebral column and spinal cord was performed. Finally, the entire length of the vertebral column was cut in 5-mm thick slices, which were processed for the histological exam.

The histopathological specimens were examined under light microscopy with different magnifications. Analysis of the histological components of the blood vessels and neuronal structures of the spinal cord in different levels were done, as well as morphometric measurements, and compared among the four groups.

To compare the morphologic changes detected in each group, Analysis of Variance (ANOVA) was used, and values of $p<0.05$ were considered significant.

\section{RESULTS}

Animals in the control group, which received normal saline, had no signs of loss of cutaneous sensitivity or compromise of motor function in any moment, indicating the absence of mechanical trauma due to the needle or volume injected. All animals that received local anesthetic developed nervous block, characterized by the absence of: cutaneous sensitivity in the lumbar and sacral regions; flexion of hind paws; and locomotion (ability to walk), when the animals awoke from general anesthesia. Group II (racemic bupivacaine) developed sensitive and motor blockade, which lasted more than 180 minutes, and residual block characterized by lack of sensitivity to electrical stimulation that persisted for 24 hours. Animals in Groups III and IV developed sensitive and motor 
blockade shortly after the puncture but, at 60 minutes, motor blockade was partially present, while the sensitive blockade lasted three hours (Figure 1).
Analysis of histological changes in the cervical and sacral spinal cord did not show significant differences among the four groups. Figures 2 and 3 illustrate the differences in

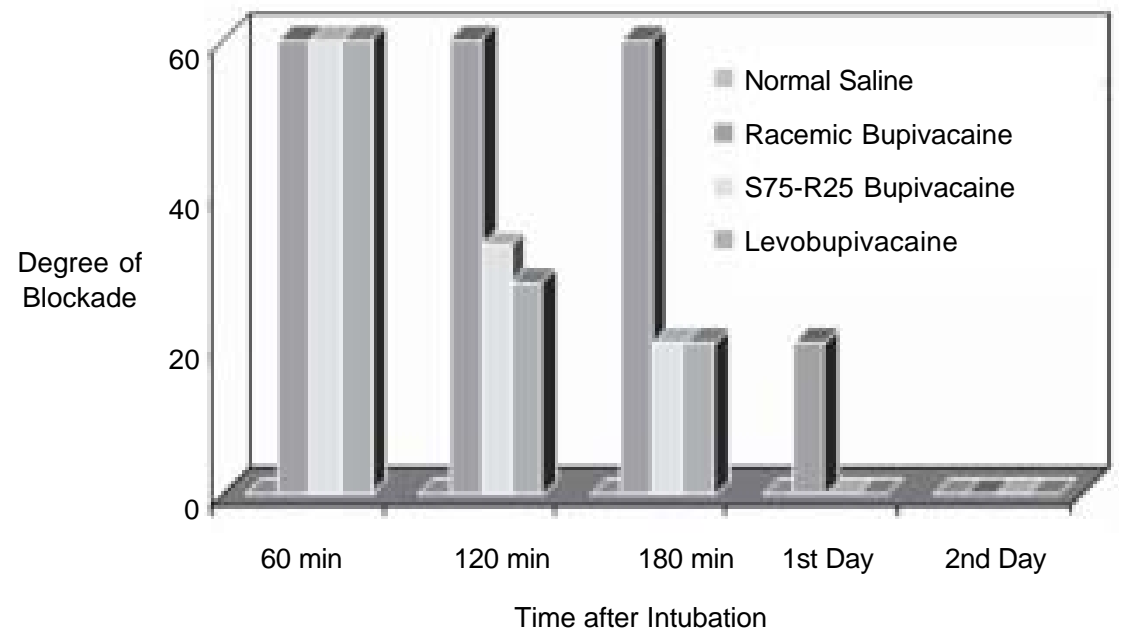

Figure 1 - Extension of Neuromuscular Blockade after Subarachnoid Injection of Anesthetics. Results obtained from the sum of the three components of the neurological exam (ability to walk, leg flexion and cutaneous sensitivity).

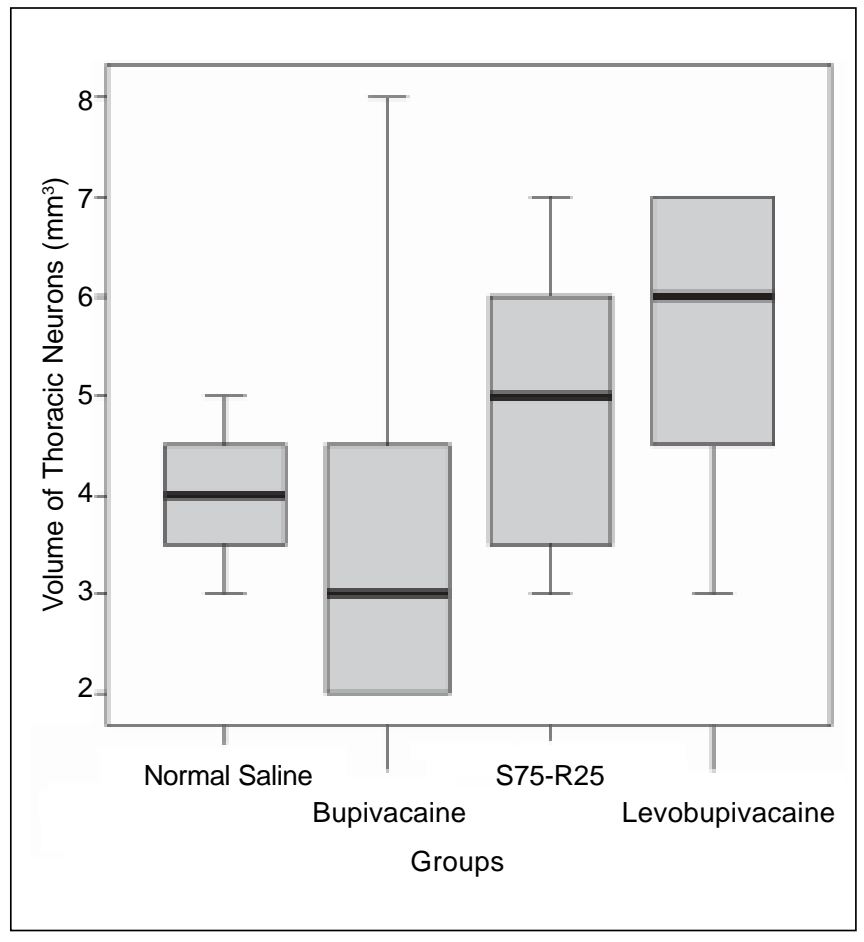

Figure 2 - Differences in the Volume of Neurons in the Thoracic Spinal Cord after Subarachnoid Administration of Large Volumes of Bupivacaine, S75-R25 Bupivacaine, and Levobupivacaine.

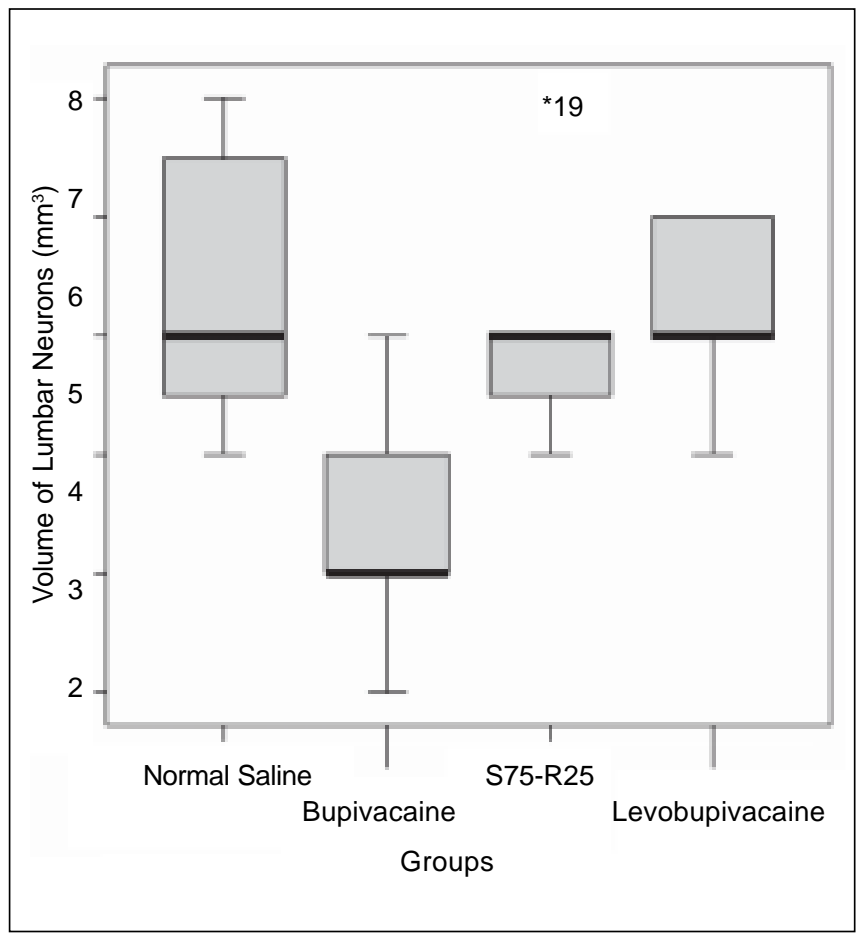

Figure 3 - Differences in the Volume of Neurons in the Lumbar Spinal Cord After Subarachnoid Administration of Large Volumes of Bupivacaine, S75-R25 Bupivacaine, and Levobupivacaine. 


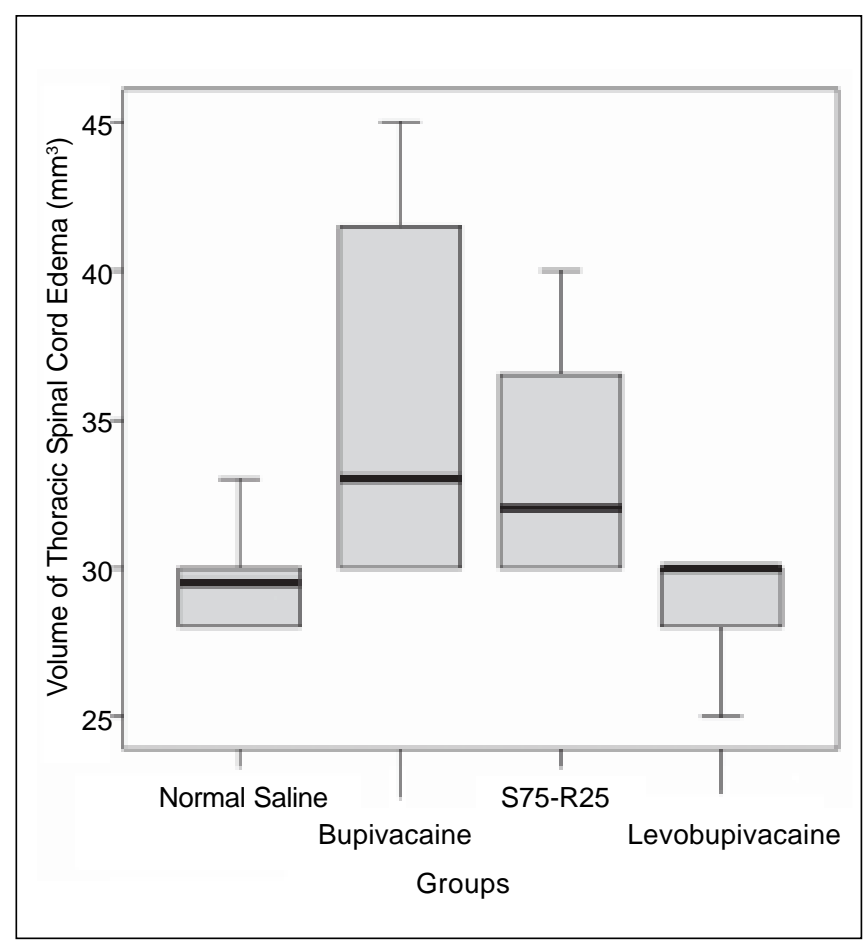

Figure 4 - Differences in the Volume of Thoracic Spinal Cord Edema After Subarachnoid Administration of Large Volumes of Bupivacaine, S75-R25 Bupivacaine, and Levobupivacaine.

cellular neuronal volume among the different groups. Both the thoracic $(p=0.002)$ and lumbar $(p=0.008)$ regions of the spinal cord of guinea pigs in Group II (bupivacaine) showed an important reduction in cellular neuronal volume when compared with the other groups.

In Figures 4 and 5 one can compare the volume of the edema in all groups. Increased edema volume in the thoracic $(p=0.015)$ and lumbar $(p=0.003)$ spinal cord were also observed. Although Group II (S75-R25) showed more morphological changes than Group IV (levobupivacaine), this difference was not statistically significant when compared with the control group. Figure 6 shows the histological view of the different groups.

\section{DISCUSSION}

In this study few histological changes in the spinal cords of guinea pigs exposed to large volumes of levobupivacaine and S75-R25 bupivacaine were observed, which were not statistically different than the control group. Administration of large volumes of bupivacaine was related with damages in the nervous system, which was statistically significant when compared with the other groups.

The results of the present study demonstrated that large volumes of levobupivacaine and S75-R25 bupivacaine produced reversible sensitive and motor blockades, even when administered accidentally. The behavior of levobupivacaine

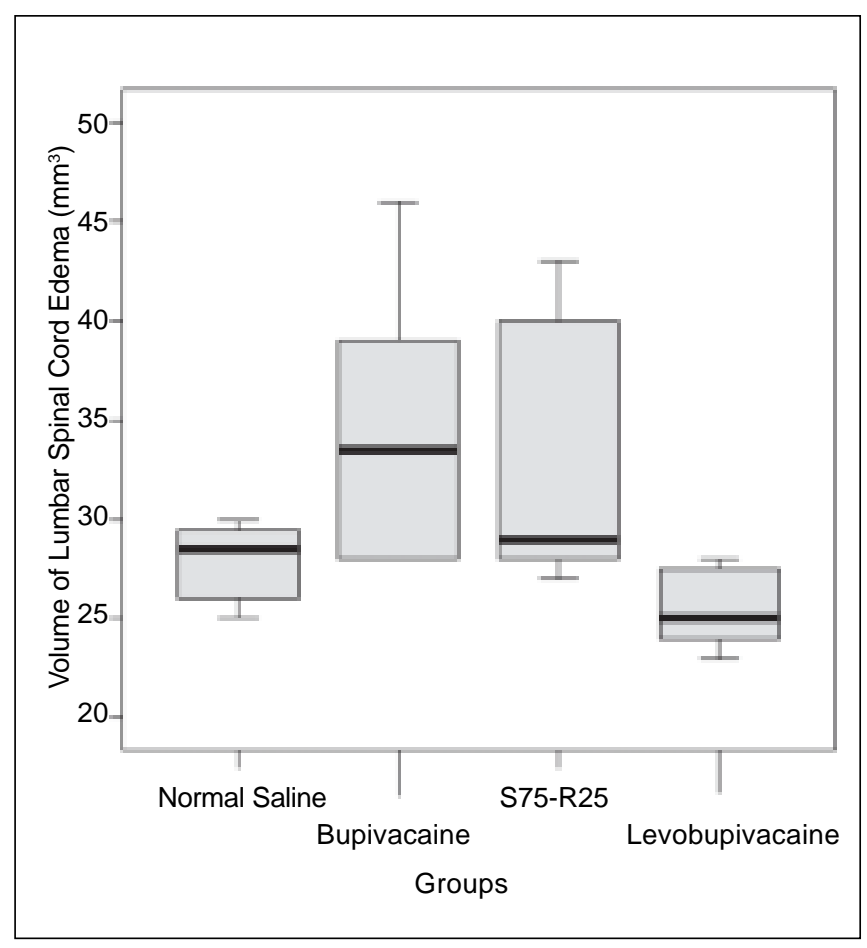

Figure 5 - Differences in the Volume of Lumbar Spinal Cord Edema After Subarachnoid Administration of Large Volumes of Bupivacaine, S75-R25 Bupivacaine, and Levobupivacaine.

was similar to normal saline. Administration of large volumes of SR50 bupivacaine was responsible for significant changes in the spinal cord when compared with the other groups.

A comparative study between the epidural and subarachnoid administration of bupivacaine, ropivacaine, and levobupivacaine in rats, by Kanai et al., demonstrated that levobupivacaine had greater anti-nociceptive effects than ropivacaine, and this was comparable to bupivacaine in concentrations of $0.25 \%$ to $0.75 \%$. When ropivacaine and levobupivacaine were administered in the subarachnoid space, in equipotent concentrations, the motor blockade produce had similar duration. When compared with low concentrations of racemic bupivacaine, the duration of the blockade produced by both anesthetics was smaller. However, in high concentrations, the duration of the blockade was similar for all three drugs. It would be interesting to know how useful experimental models are on identifying the neurotoxicity of local anesthetics. There are some experimental models used to study regional anesthesia in small animals ${ }^{20-23}$. In 1998, a model of regional anesthesia in guinea pigs, with only a single paramedian puncture with a 23-gauge needle in the $L_{6}-S_{1}$ space, was described. The authors demonstrated, with the administration of methylene blue, that the puncture reached the subarachnoid space without damaging the spinal cord or nerve roots ${ }^{19}$. Part of this model, without the methylene blue, was used in the present study; the presence of anesthesia was demonstrated by the clinical-neurological exam. The guinea 


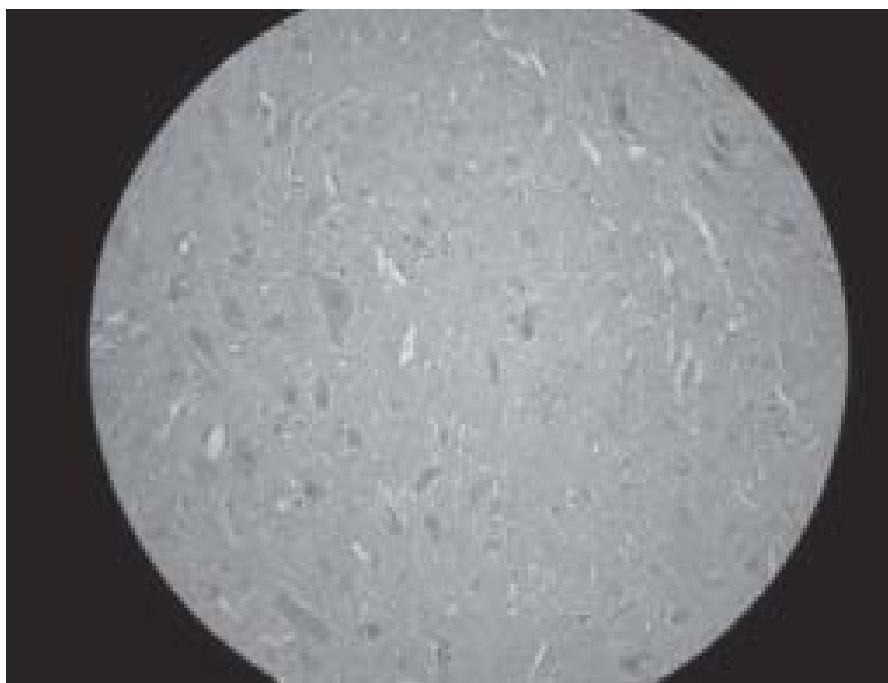

Control Group

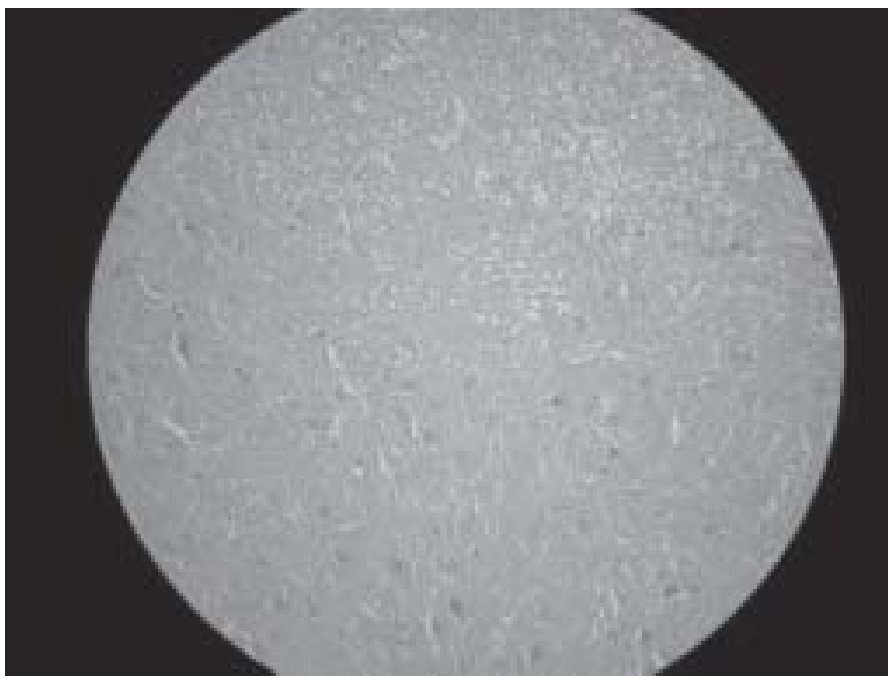

S75-R25 Bupivacaine

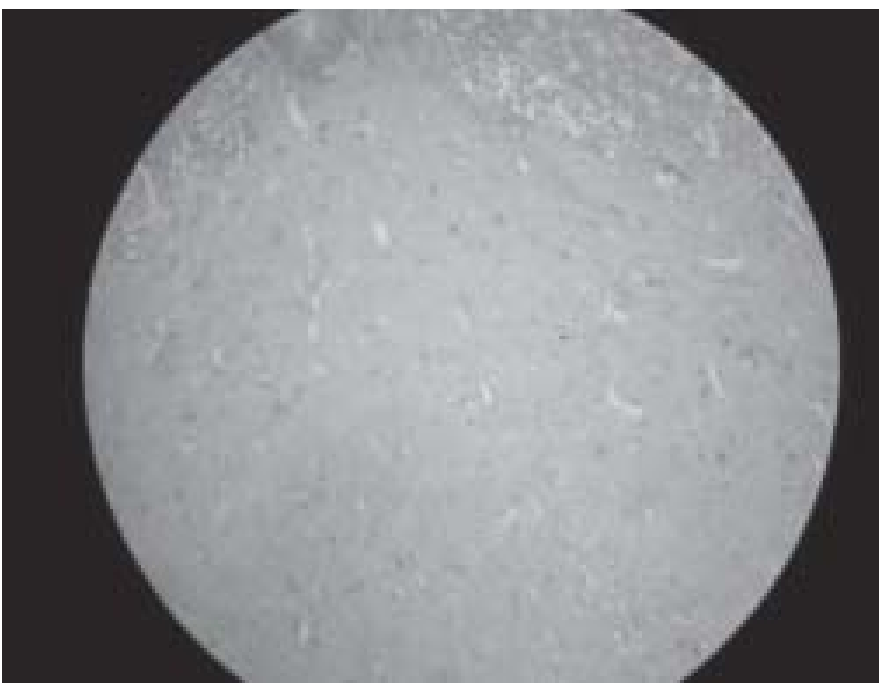

Bupivacaine

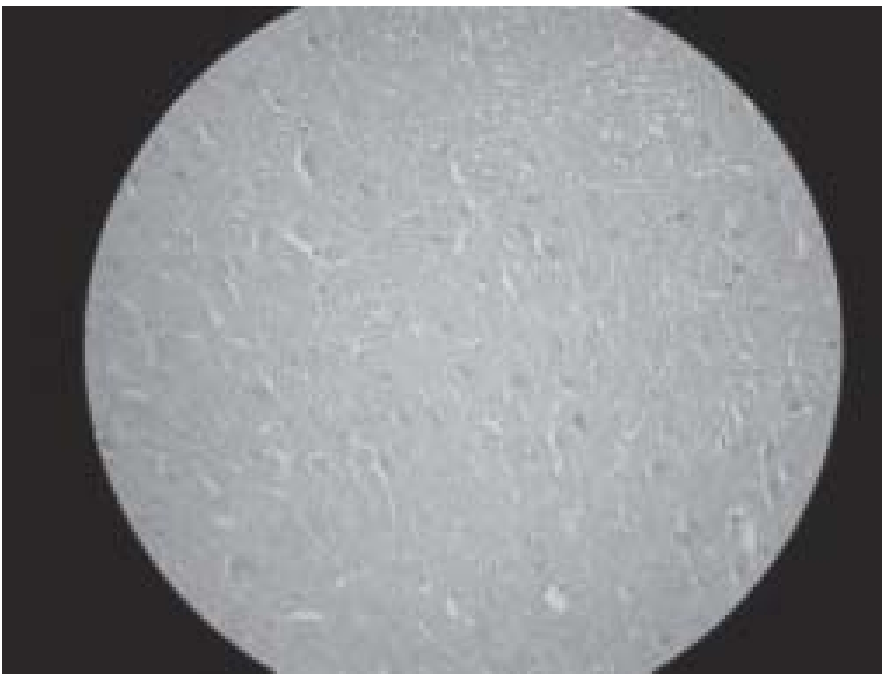

Levobupivacaine

Figure 6 - Microscopic View of the Spinal Cord of Guinea Pigs (Lumbar) After Administration of the Respective Drugs.

pig was chosen because it is a docile animal and easy to evaluate, which was convenient for the present study. To decrease animal suffering, we decided to use general inhalational anesthesia, which also allowed total immobilization of the animal. Since the spinal cord of the guinea pig runs down to the lumbar region, the intervertebral space below the lumbar spine $\left(L_{6}-S_{1}\right)$ was chosen ${ }^{18,24}$.

Very little is known about the mechanisms by which local anesthetics produce nerve lesions. It is only known that, when clinical manifestations develop, the lesions are severe enough to produce loss of conduction in some populations of nerve fibers ${ }^{15-17}$. It is known that, after the subarachnoid administration of local anesthetics, the metabolism of the spinal cord can decrease due to the intense sensitive and motor blockade. It is possible that the local anesthetic, in high concentrations, determines the irreversible blockade of intracellular transport, and this could contribute for the development of paresis and paralysis observed after regional blocks. Cell death is not necessary for the development of functional changes because toxic reactions in any population of cells or receptors can influence neurological function ${ }^{16,20,25}$. When large volumes of local anesthetics are inadvertently injected in the subarachnoid space, the tamponade and dilution that are normally seen with small volumes cease to exist. The possibility of greater exposure of the lumbar and sacral regions of the spinal cord and of the sacral nerve roots to the local anesthetic increases. The blood vessels of the spinal cord, that usually dilate, could undergo vasoconstriction, leading to spinal cord suffering ${ }^{20,25}$.

The volume of anesthetic used in the present study was approximately four times greater than the standardized dose for anesthesia in animals. Prior pilot studies demonstrated 
that smaller volumes did not allow the identification of a number of neurologic lesions that differed significantly from the control group. For the development of cellular changes, such as of apoptosis and cell death, the concentration of the local anesthetic has to be higher than doses that produce irreversible blockade of sodium channels. Use of high concentrations can produce permanent neurologic changes ${ }^{19,26}$. The methodology of studies on the toxicity of local anesthetics includes intense manipulation of the study animals, including the insertion of catheters and the possibility of spinal cord damage. New studies try to find the minimal effective dose of local anesthetics (MLAC) and very few studies focus on the effects of large volumes of local anesthetics. The search for less traumatic methods leads to more confidence on the results.

Accidental injection of large volumes of local anesthetics in the subarachnoid space is a possible complication of epidural anesthesia ${ }^{14,15}$. Over the last few years, the safety of this anesthetic technique has increased due to the possibility of administering local anesthetics with fewer side effects ${ }^{9,13}$.

Large volumes of levobupivacaine caused little damage of the nervous system when compared with bupivacaine. Statistically significant differences were not observed between levobupivacaine and S75-R25.

\section{REFERÊNCIAS - REFERENCES}

01. Tetzlaff JE - The pharmacology of local anesthetics. Anesthesiol Clin North Am, 2000;18:217-233.

02. Ritchie JM, Greene NM - Local Anesthetics, em: Gilman AG, Rall TW, Nies AS et al. - The Pharmacological Basis of Therapeutics. New York, Pergamon, 1990;311-329.

03. Stoelting RK - Anestésicos Locais, em: Stoelting RK - Manual de Farmacologia e Fisiologia na Prática Anestésica. São Paulo, Artes Médicas, 1997;100-114.

04. Stoelting RK - Anestésicos Locais, em: Barash PG, Cullen BF, Stoelting RK - Manual de Anestesiologia Clínica. São Paulo, Manole, 1991;223-242.

05. Strichrtz GR, Cocino BG - Local Anesthetics, em: Miller RD Anesthesia. $3^{\text {rd }}$ Ed., New York, Churchill Livingstone, 1990;437465.

06. McClellan KJ, Spencer CM — Levobupivacaine. Drugs, 1998;56: 355-362.

07. Foster RH, Markham A - Levobupivacaine: a review of its pharmacology and use as a local anaesthetic. Drugs, 2000;59: $551-579$

08. Simonetti MPB, Valinetti EA, Ferreira FMC - Avaliação da atividade anestésica local da S(-) bupivacaína: estudo experimental in vivo no nervo ciático de rato. Rev Bras Anestesiol,1997;47: 425-434.

09. Kopacz DJ, Allen H, Thompson G - A comparison of epidural levobupivacaine $0.75 \%$ with racemic bupivacaine for lower abdominal surgery. Anesth Analg, 2000;90:642-648.

10. Vladimirov M, Nau C, Mok WM et al. - Potency of bupivacaine stereoisomers tested in vitro and in vivo. Anesthesiology, 2000; 93:744-755.

11. Simonetti MPB, Ferreira FMC - Does the D-isomer of bupivacaine contribute to the improvement of efficacy in neural block? Reg Anaesth Pain Med 1999;24(suppl):43.
12. Simonetti MPB, Bird RA - Evaluation of new local anesthetics obtained through the manipulation of the enantiomeric ratio of bupivacaine on the central nervous system of the rat. Int Monitor, 2000;12:129.

13. Delfino J, Vale NB - Bupivacaína levógira a $0,5 \%$ pura versus mistura enantiomérica de bupivacaína (S75-R25) a 0,5\% em anestesia peridural para cirurgia de varizes. Rev Bras Anestesiol, 2001;51:474-482.

14. Ben-David B, Rawa $R$ - Complications of neuraxial blockade. Anesthesiol Clin North Am, 2002;20:669-693

15. Munnur U, Suresh MS - Backache, headache, and neurologic deficit after regional anesthesia. Anesthesiol Clin North Am, 2003;21:71-86.

16. Beardsley D, Holman S, Gantt R et al. - Transient neurological deficit after spinal anesthesia: local anesthetic maldistribution with pencil point needles? Anesth Analg, 1995;81:314-320.

17. Lambert DH, Hurley RJ - Cauda equina syndrome and continuous spinal anesthesia. Anesth Analg, 1991;72:817-819.

18. Drasner K, Rigler M, Sessler DI et al. - Cauda equina syndrome following intended epidural anesthesia. Anesthesiology, 1992; 77:582-585.

19. Capelozzi M, Arantes FM, Paiva PSO et al. - Spinal anesthesia increases pulmonary responsiveness to methacholine in guinea pigs. Anesth Analg, 1998;87:874-878.

20. Ready LB, Plumer MH, Haschke RH et al. - Neurotoxicity of intrathecal local anesthetics in rabbits. Anesthesiology, 1985; 63:364-70.

21. Bahar M, Rosen M, Vickers MDV. Chronic cannulation of the intradural or extradural space in the rat. $\mathrm{Br} J$ Anaesth, 1984,56:405-10.

22. Durant PAC, Yaksh TL - Epidural injections of bupivacaine, morphine, fentanil, lofentanil, and DADL in chronically implanted rats. A pharmacologic and pathologic study. Anesthesiology 1986, 64: 43-53.

23. Kannai Y, Tateyama S, Nakamura T et al. - Effects of levobupivacaine, bupivacaine and ropivacaine on tail-flick and motor function in rats following epidural or intrathecal administration. Reg Anesth Pain Med, 1999,24:444-452.

24. Cooper G, Schiller A - Guinea Pig Anatomy. $1^{\text {st }}$ Ed., Harvard University, 1980;152-153.

25. Ganem EM, Vianna PTG, Marques M et al. - Efeitos da administração subaracnóidea de grandes volumes lidocaína a $2 \%$ e ropivacaína a $1 \%$ sobre a medula espinal e as meninges. Estudo experimental em cães. Rev Bras Anestesiol, 2003;53:351-360.

26. Myers RR, Sommer C - Methodology for spinal neurotoxicity studies. Reg Anesth, 1993;18:439-447.

\section{RESUMEN}

Vasconcelos Filho PO, Posso IP, Capelozzi M, Capelozzi VL Comparación de las Alteraciones Histológicas de la Medula Espinal y Neurológicas de Hámsteres después de la Anestesia Subaracnoidea con Grandes Volúmenes de Bupivacaina Racémica, de Mezcla con Exceso Enantiomérico de 50\% de Bupivacaína (S75-R25) y de Levobupivacaína.

JUSTIFICATIVA Y OBJETIVOS: La levobupivacaína presenta menores efectos colaterales sobre el sistema nervioso central, si los comparamos con los inducidos por la bupivacaína racémica, sin embargo el efecto anestésico es menos intenso. Fue realizado un estudio experimental para comparar efectos adversos de grandes volúmenes de bupivacaína, de bupivacaína S75-R25 y de levobupivacaína cuando se inyectaron en el espacio subaracnoideo de los hámsteres. 
COMPARISON OF HISTOLOGIC SPINAL CORD AND NEUROLOGIC CHANGES IN GUINEA PIGS AFTER SUBARACHNOID BLOCK WITH LARGE VOLUMES OF RACEMIC BUPIVACAINE, 50\% ENANTIOMERIC EXCESS BUPIVACAINE (S75-R25), AND LEVOBUPIVACAINE

MÉTODO: Cuarenta hámsteres se dividieron en cuatro grupos. Anestesiados con $\mathrm{O}_{2}$ a $100 \%$ e isoflurano a $2 \%$, con posterior punción en el espacio intervertebral $L_{6}-S_{1}$. En los animales del Grupo I se administraron $2 \mathrm{~mL}$ de solución fisiológica a 0,9\%; en el Grupo II, 2 mL de bupivacaína 0,5\%; en el Grupo III, 2 mL de bupivacaína S75-R25 0,5\% y en el Grupo IV, $2 \mathrm{~mL}$ de levobupivacaína 0,5\%. Después del despertar, en los momentos 0,60, 120 y 180 minutos, fue realizado examen neurológico diariamente por una semana. Los animales fueron sacrificados y sometidos a la perfusión con paraformaldeido a 4\%. Después de la fijación, la médula espinal fue aislada por disección y analizada histológicamente para evaluar el grado de lesión medular.
RESULTADOS: Los hámsteres del grupo control no presentaron bloqueo nervioso. Los del Grupo II presentaron bloqueo sensitivo y motor por más de 180 minutos. En los Grupos III (S75-R25) y IV (levobupivacaína) hubo un bloqueo motor y sensitivo al momento 0 minuto, sin embargo al momento 60 minutos el bloqueo motor era mínimo. En el examen histológico, el Grupo I no presentó alteraciones. En el Grupo II fueron encontradas alteraciones medulares intensas. En el Grupo III y IV las alteraciones medulares fueron poco intensas.

CONCLUSIONES: La levobupivacaína en grandes volúmenes causó poco daño al sistema nervioso comparada a la bupivacaína. Entre la levobupivacaína y la bupivacaína S75-R25, no hubo diferencia estadística significativa. 